\title{
THE DIGITAL DALIT: SUBALTERNITY AND CYBERSPACE
}

This essay proposes that online spaces - cyberspace - constitute an important new space for the subaltern. It maps the emergence of a subaltern cyberspace with interesting and important consequences not only for the Dalits - the 'untouchable' castes of India but for political culture in the age of digital media.

Here, we need to see cyberculture as an extension of technoculture and therefore factor in the uneven, even prejudicial, movement of technology, accounting for the role of institutional, commercial, state and social actors, and their power relations, in determining India's Information Technology (IT) policy. Beth Kolko's work has demonstrated, for instance, how local cultural practices have determined internet usage and development policies in Central Asia (2006). We need to see online lives and cultures as extending into and drawing upon real-life social conditions. I have elsewhere proposed that the digitalvirtual will always intersect with the material and the real and therefore we need to see these technologies as having consequences for real bodies, emotions, places and economies (Nayar 2010, Introduction to New Media). Hence we have to speak of the materialization of online lives and the digitization of material lives for commercial, political and other purposes. Finally, cybercultures are extensions also of existing social and cultural practices. That is, technologies, including digital technologies, are embedded in the cultures that produce them, and we need to be alert to the social order from which particular technologies and policies about them have emerged. Cyberspace itself might be read as a set of social practices, which have exclusionary and inclusionary potential depending on the politics of use.

Keeping the above provisos as a cautionary backdrop, it is important to note that. as of date, there are no studies of Dalit access to and usage of new media technologies in India. In India, where Dalits struggle at the lower end of the social ladder for education, employment and 'bare life' itself, 'access' is a major issue. Admittedly, access is marginally better for students enrolled in universities or Dalits in metropolises with more computers and better connectivity, even if they do not buy individual computers. While state-sponsored efforts at 'connecting' villages and communities are underway, the digital divide as far as Dalits are concerned, we can assume, remains unbridged. So much for the question of access. There is also the question of how subalterns use the new media technologies. Studies of digital cultures in India have ignored the subaltern presence in cyberspace - indicative of this bias is a volume like Nalini Rajan's Digital Culture Unplugged: Probing the Native Cyborg's Multiple Locations (2007), which does not carry

The Sri Lanka Journal of the Humanities' XXXVII (1\&2) 2011 
a single essay on Dalits in cyberspace. Other commentators such as Rohit Chopra (2006) have detected a 'global primordiality' at work in online Dalit self-representations, which intersects, problematically, with right-wing Hindutva self-representations. However, this reading ignores the very astute and subversive counter-publics being formed through not only an emphasis on their primordiality but through an insertion into contemporary debates about rights. This latter is my interest in the present essay. I am interested in the uses to which new media and specifically internet cultures are put to by Dalits in India.

However, as texts, I have chosen to focus on Dalit organizations with strong web presence, and have left out personal blogging and corporate-commercial interests driven digital Dalits like the Dalit Indian Chamber of Commerce and Industry.

\section{New Media and Alternative History}

Central to Dalit websites is the construction of a different, or alternative, history of India. Focusing on the historically sanctioned and severely oppressive caste-system, websites offer a sociological account of the Hindu social order that enabled the uppercastes to subjugate the 'lower'. Thus the Dalit Freedom Network has a quick definition for the uninitiated, 'Who are the Dalits?' $)$. In the case of this particular website, what we get is a transnational frame in which to read India's dark history: the caste system is compared to slavery: 'Dalits constitute the largest number of people categorized as victims of modernday slavery'. I shall return to the issue of transnationalism later.

Another website, Dalitistan.org, now defunct, hosted the Sudra Holocaust Museum. ${ }^{2}$ The Museum gives viewers a more detailed exploration of the history of what Dalits refer to as genocide. It cites evidence from Hindu texts such as the Manusmriti where the most horrific punishments were prescribed for Dalits if they violated the castebarrier. But what is most crucial here is the documentation of caste-based violence in post1947 India, sourced from news reports and TV coverage of Dalit torture and killings. The website also offers information on serious social issues such as child labour in India, and a National Geographic feature on Indian untouchability, complete with links to documentaries such as Lesser Humans. ${ }^{3}$ The International Dalit Solidarity Network (IDSN, http://www.idsn.org/) also offers documentaries about Dalit lives.

The hypertextual nature of the digital medium enables one to explore links to news reports, videos and other documents. Key texts that deal with Hinduism and the caste system such as as Jyotiba Phule's work on 'slavery in the British Empire', the writings of B.R. Ambedkar, and Human Rights Watch's iconic exposure of India's contemporary history of anti-Dalit violence, Broken People are archived at Dalitistan. ${ }^{4}$ It also archives the

\footnotetext{
${ }^{1}$ http://www.dalitnetwork.org/go?/dfn/who are the dalit/C64)

Now archived at http:/web.archive.org/web/20060510020849/http://dalitstan.org/holocaust/, though it has not been updated since 2001 .

http web.archive org web 20060504211004 http: wWw thirdworldtraveler com/IMF W'B SmallHa nds MNM.html

${ }^{4}$ http /web.archive.org/web/20060426034818/htip//www dalitstan.org/books/index.html.
} 
Sri Krishna Commission Report on the Bombay riots of 1993 in which the role of Hinduforces had been exposed (see especially Chapter III of the Report). ${ }^{5}$

The documentation of atrocities and incidents of violence, alongside the histories of the same, are modes of constructing a cultural memory. I have elsewhere argued (Nayar 2010, 'Information Spaces') that we need to see digital archives as being less about the present or the past than about the future because they represent the aspirations of the people: how will the future interpret these "texts"? The cultural memory that these archives compile, dating back, in the case of the Sudra Holocaust Museum, to ancient India, constitutes a veritable genealogy of oppression. Using individual incidents, personal narratives, and newspaper coverage the archive here disdains the mere Amnesty-style statistical account of discriminatory violence. It is preciscly in the mix-and-match genres, the multimodal presentations of the violence, that a different story is told for, as Richard Wilson has argued, statistical accounts are 'minimalist' and 'strips events of their subjective meanings in pursuit of objective legal facts' (2009: 209).

\section{Communities of Interest}

Such an alternative global history of suffering and genocide generates, and is fuelled by, the formation of communities of interest online. Dalits from around the world can now meet and discuss issues and concerns that affect them. A virtual community of the concerned and the vulnerable - what we can think of as 'communities of interest' - is made possible due to the internet. It offers others, moved by the spectacle of suffering, to become 'cultural insiders' to genocide, oppression and torture.

These communities of interest, or 'webs of affinity', as Lisa Nakamura terms them (2002: 102) - initially dealing with India, Nepal and Bangladesh, now incorporate into their vision fields and fields of action, issues normally ignored by Dalits in India. The IDSN Annual Report of 2010 is thus able to note as a 'highlight' the following:

The UK government included a caste clause in the Equality Bill, pending a report of evidence.

The UK government commissioned report found evidence of caste discrimination in the UK.

The Dutch Foreign Minister spoke out against caste discrimination in the UN Human Rights Council. ${ }^{6}$

The UN's treaty body recommendations for dealing with countries on the website gives links to extensive studies and reports on the caste system, such as the New York University's Centre for Human Rights \& Global Justice (NYU School of Law and Human

\footnotetext{
${ }^{5}$ http:/ web.archive.org web 20050310)150105: http: Www dalitstan org mughalstancatl krishnakil 3.html

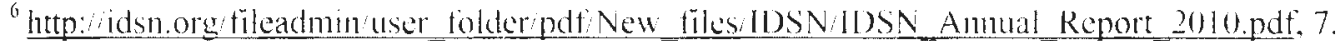


Rights Watch) 'India's Hidden Apartheid'? The IDSN also links with United Nations and European Union documents and sites dealing with discrimination. ${ }^{8}$

What this does is to situate an alternative history of India as the history of discrimination, but one which intersects with global concerns about race and race-based discrimination. Therefore, one needs to see the self-representation of Dalits in such websites as becoming transnationalized by appealing to and fitting themselves into a global historical narrative of oppression, torture and trauma. What I am proposing here is a counter-flow to global 'flows' (Manuel Castells and Arjun Appadurai's famous terms to describe globalization) of capital, people and commodities where a transnationalization of suffering and human rights concerns are also made possible through the new media. Strategically this enables the Dalits in India to acquire global visibility and therefore leverage. IDSN's recommendations to the EU, for instance, suggest this leverage, and results in the Swedish Premier's speech at the Human Rights Council that 'Caste-based discrimination and other forms of discrimination based on work and descent is an important priority for the European Union' (cited in the IDSN Annual Report $2009^{9}$ ).

Dalit activism when it goes online enables a transnational subaltern project, seeking and establishing links with sympathizers, activists, NGOs, transnational organizations as well as with other histories of oppression - the blacks, mainly, but also African Americans. Thus the 'alternative history' I began with here must be redefined as 'alternative global history' where linkages across geography and geopolitical boundaries based on a shared vulnerability and suffering are possible through new media.

Thirumal and Tartakov (2011) suggest that new media and information technologies offer the Dalits, otherwise denied a space for self-representation, an entry into the nation's internal discourses. While this is certainly true in the case of the websites examined here, what cannot be ignored are the determined efforts made by these websites to incorporate international Human Rights laws, transnational linkages and global activism into their discourses. This suggests that Dalit websites are as keen on attracting the attention of global discourses - and thereby their insertion into the same - even as they seek to bring international pressure to bear upon the Indian state to address the question of caste-based oppression.

\section{Dalit Agency Online}

Communities of interest that produce linkages across shared concerns over discrimination accrue political presence and weight over a period of time. Community services, as evidenced in the case of blacks in the USA (Ebeling 2003), are facilitated by online links. Diasporic, minority communities and the blacks in the First World have begun to access cyberspace for community services, education, health, and cultural memory projects, even though the digital divide persists. ${ }^{10}$ It enables the spread of information

\footnotetext{
${ }^{7}$ http://idsulorg/fileadmin'user_folder/pdf/Old_files/un/pdf/CHRGJ-HRW_CERD\%20.pdf.

${ }^{8} \mathrm{http} / / \mathrm{idsn}$.org/international-advocacy/un/; http//idsn.org/international-advocacy/eu/

9 http: idsn.org fileadmin user folder pdf New_files FI' IDSN_Annual Repon_2009 EU chapter.pdf, 12.

II" A January 2011 report by the Pew' Research Center under the 'Pew Internet and American Life' survey has noted that new digital divides are now visible with cyber-segregation along the lines of real-life segregation, ironically due to excess access (see http://www.pewinternet.org/MediaMentions/2011/For-minorities-new-digital-divide-seen.aspx)!
} 
about laws and statutes that have sought to reduce caste-based oppression and Dalit rights. (For example, Dalit Foundation has links to The Scheduled Castes and the Scheduled Tribes [Prevention of Atrocities] Act, 1989, The Protection of Women from Domestic Violence Rules, 2005). "Agency' here is the construction of a public sense of wrongdoing, of bringing-to-visibility the histories of oppression so that the civil society's complacence is shaken. While one might argue about the efficacy - juridical, political - of these online documents and texts, their key intervention, in my view, is in the social spheres. The technology thus creates and widens out a culture of dissent, awareness and therefore social change over a period of time. Online activism by Dalits constitute a counterpublics where the public sphere is extended into cyberspace but where mainstream ideologies of secularism and democracy are fiercely contested through the counterrepresentations on these websites. When Ann Travers makes a case for a feminist counterpublics in cyberspace, we can readily visualize such a moment and movement for Dalits.

To take just one instance, that of resources for debating the contemporary. The digital archive of Ambedkar and commentaries by scholars like Kancha Ilaiah online enable the dissemination of radical thought. ${ }^{12}$ Debates over contemporary issues - most recently over the controversial Hindi film on affirmative action, Aarakshan, 2011, by Ravi Kumar (Dalits Media Watch) - enable scholarly and informed debates about not only caste but also Indian media, mass culture, state policy. ${ }^{13}$ Without the limitations of place that print media suffers from, online discussions and coverage reach a wider community and this changes the political culture of, say, youth and like-minded people. Individuals and volunteers, as these websites show, have joined the campaigns against fundamentalism, caste-based oppression, social equality and gender empowerment. These campaigns have brought to the notice of the wider community the problems with globalized India's shift toward increasing privatization - the private sector does not implement the state policies on affirmative action - and thus the denial of access to the Dalits.

In a world where the virtual increasingly intersects with the real, Indian civil society has the potential to be reinvigorated as more and more subalterns - and here I am moving beyond the Dalits - take to the virtual to create new cultures of the political. Dalit blogging might result in the public (re)construction of the self - the standard argument about virtual lives - - but from what has thus far gone online, the individual (except in the case of high-profile ones like Meena Kandasamy, http://meenu.wordpress.com/) has been largely invisible in favour of communitarian presences. This in itself suggests that the digital Dalit seeks communitarian and collective identities online, effacing the individual in favour of a group. ${ }^{14}$

${ }^{11}$ http:/www dalitfoundation.org/actsnprovisions. htm.

${ }^{12} \mathrm{http} / /$ web.archive.org/web/20060426034818/http:/www.dalitstan.org/books/index.html See also www ambedkar.org.

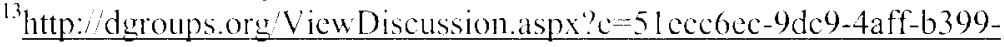

$8130698414 a b \& \mathrm{i}=9 \mathrm{aa} 99 \mathrm{c} 2 \mathrm{c}-\mathrm{e} 5 \mathrm{db}-452 \mathrm{c}-\mathrm{b} 15 \mathrm{~d}-\mathrm{b} 24 \mathrm{c} 8 \mathrm{e} 3932 \mathrm{cb}$.

${ }^{14}$ A quick framework for reading individual blogs like hers would be as follows. Meena Kandasamy ensures that she 'connects' and situates herself in the community/easte, moving swiftly across the 'real' or historical 'I' (the Tamizh poet called Meena Kandasamy), the narrating 'I' and the narrated 'I' (the profile-management online she performs) and the ideological 'I' (her new subjectivity made possible through the availability of new technologies). 
The presence of reportage and personal stories on these websites are crucial interventions in the social, civic and political narratives of the nation as a whole. New technologies do of course enable the reformatting of the self (via profile management, online avatars, networked relations, etc), but they also function as technologies of the communitarian self when stories of violation enter the digital world. The Digital Dalit marks a necessary interruption in the otherwise elite discourses and uses of cyberspace.

\section{References}

Chopra, Rohit. 'Global Primordialities: Virtual Identity Politics in Online Hindutva and Online Dalit Discourse', New Media and Society 8.2 (2006):187-206.

Ebeling, Mary F.E. 'The New Dawn: Black Agency in Cyberspace', Radical History Review 87 (2003): 96-108.

Kolko, Beth E. 'Cultural Considerations in Internet Policy and Design: A Case Study from

Central Asia', Critical Cyberculture Studies. Ed. David Silver and Adrienne Massanari. New York: New York UP, 2006. 119-128.

Nakamura, Lisa. Cybertypes: Race, Ethnicity, Identity on the Internet. New York: Routledge, 2002.

Nayar, Pramod K. An Introduction to New Media and Cybercultures. Malden, MA: WileyBlackwell, 2010.

-. 'Information Spaces, Digital Culture and Utopia', Journal of Contemporany Thought 31 (2010): 113-132.

Rajan, Nalini. Ed. Digital Culture Unplugged: Probing the Native Cyborg's Multiple Locations. New Delhi: Routledge, 2007.

Thirumal, P and Gary Michael Tartakov. 'India's Dalits Search for a Democratic Opening in the Digital Divide', International Exploration of Technology Equity and the Digital Divide: Critical, Historical and Social Perspectives. Ed. Patricia Randolph Leigh. Hershey, New York: Information Science Reference, 2011. 20-39.

Travers, Ann. 'Parallel Subaltern Feminist Counterpublics in Cyberspace', Sociological Perspectives 46.2 (2003): 223-37.

Wilson, Richard. 'Representing Human Rights Violations: Social Contexts and Subjectivities', Human Rights: An Anthropological Reader. 1997. Ed. Mark Goodale. Malden, MA: Wiley-Blackwell, 2009. 209-228. 